\title{
Cholesterol affects African swine fever virus infection
}

\author{
C. Bernardes ${ }^{a}$, A. António ${ }^{a}$, Maria C. Pedroso de Lima ${ }^{b}$, M.L. Valdeira ${ }^{a}, *$ \\ a Department of Cellular $\alpha$ Biology, Faculty of Pharmacy, University of Lisbon, Avenida das Forças Armadas, 1600 Lisbon, Portugal \\ b Department of Biochemistry, Apartado 3126, University of Coimbra, 3049 Coimbra Codex, Portugal
}

Received 10 March 1998; accepted 22 April 1998

\begin{abstract}
African swine fever virus (ASFV) enters cells by receptor mediated endocytosis and requires a fusion event between the viral envelope and the limiting membrane of the endosome at low $\mathrm{pH}$. In order to investigate the role of cholesterol in the early stages of ASFV infection, we have studied the effect of the removal of cell and viral membrane cholesterol by cholesterol oxidase treatment of cells and virions, as well as the effect of some inhibitors of cholesterol synthesis on the infectious pathway. In addition, we have investigated viral infection in cholesterol-depleted Vero cells. Both cholesteroldepleted and cholesterol oxidase-treated Vero cells were unaltered in their ability to bind or internalize the virus, but were blocked in ASFV fusion and subsequent virus replication. Our results indicate that ASFV infection is affected by cholesterol in the target membrane. (C) 1998 Published by Elsevier Science B.V. All rights reserved.
\end{abstract}

Keywords: African swine fever virus; Cholesterol; African swine fever virus penetration; African swine fever virus fusion; African swine fever virus entry

\section{Introduction}

African swine fever virus (ASFV), the only representative of an as yet unnamed family of DNA viruses, is a cytoplasmic virus with an icosahedral capsid surrounded by two lipid envelopes [1]. ASFV is responsible for an important and highly contagious disease which attacks domestic pigs causing heavy economic losses [2]. The available data show that ASFV enters sensitive cells by a process of receptor mediated endocytosis $[3,4]$, and that the fusion of the viral membrane with the membrane of an endosome is triggered at the acidic $\mathrm{pH}$ generated in this organ-

\footnotetext{
* Corresponding author. Fax: +351 (1) 7946435; E-mail: lvaldeira@ff.ul.pt
}

elle, in order to deliver the viral DNA into the cytoplasm [5].

It has been previously shown, using sensitive and simple fluorescence assays, that ASFV is able to fuse with liposomes of various lipid compositions, and that the fusion is more extensive with negatively charged phospholipids, cardiolopin (CL) or phosphatidylserine (PS), and is reduced in the presence of the zwitterionic phospholipid phosphatidylcholine (PC), but not phosphatidylethanolamine (PE) [6]. However, the effect of lipid composition on viral penetration and cell infection has not yet been studied. Cholesterol is a major component of cell membranes, exhibiting different effects on membrane fusion, depending on the experimental system studied. These systems include the fusion of enveloped viruses with target membranes, such as liposomes [7-9], and cultured cells [9-11]. For example, modulation of viral 
membrane fusion by cholesterol appears to have different effects depending on the system studied. For example, fusion of Semliki Forest virus (SFV) $[10,11]$ and Sendai virus [12] required cholesterol in the target cell membrane or liposome, although in another study cholesterol appeared to decrease Sendai virus fusion [13]. On the other hand, supplementation of cells with cholesterol (resulting in increased membrane cholesterol/fatty acid ratio) led to a marked enhancement of mouse hepatitis virus-mediated cell fusion [14].

Some of the above studies were done employing $\mathrm{W}-7$, cerulenin and miconazole, which are known to suppress cholesterol metabolism in a variety of cell types [15], to investigate the effects of cholesterol on viral fusion and infectivity [16]. Another method consisted of studying the importance of this sterol in the fusogenic activity of viruses by measuring fusion with erythrocyte membranes enriched or depleted of cholesterol upon incubation with cholesterol-rich liposomes or pure phospholipid liposomes [17]. Mutant cells defective in cholesterol biosynthesis have also been used to ascertain the role of cholesterol in the fusion of Sendai virus [18]. The cholesterol content of the virus membrane may also be a determinant of the fusion activity of the virus. In certain viruses such as SFV, the fusogenic activity is independent of the presence of cholesterol in the "virosome' membrane [19]. On the other hand, VSV and Sendai virus need this sterol in their envelopes for fusion activity [20,21].

The purpose of the present work was to investigate the importance of cholesterol in cell infection by ASFV (1) by altering the cell cholesterol metabolism, (2) by altering the cholesterol levels either of the virus or the cell membrane, and (3) using sterol-depleted cells.

Our results show that all the above procedures result in a significant inhibition of infectivity of Vero cells by ASFV, suggesting a crucial role of cholesterol in the early stages of this process.

\section{Materials and methods}

\subsection{Cells and virus}

Vero cells (obtained from ATCC, USA) were grown as monolayers in Dulbecco's modified Eagle's medium (DME) supplemented with 10\% newborn calf serum (NCS) and gentamicin $(50 \mu \mathrm{g} / \mathrm{ml})$, both purchased from Gibco (Scotland). The Lisbon 60 strain of ASFV was a gift from Dr. J. Vigário [22]. Adaptation to grow in monkey cells was produced in Vero cells, as described [23]. To produce labeled virus, $20 \mu \mathrm{Ci} / \mathrm{ml}$ of $\left[{ }^{3} \mathrm{H}\right]$ thymidine (specific activity 50 $60 \mathrm{Ci} / \mathrm{mmol}$, Amersham, England) was added to the medium following $2 \mathrm{~h}$ infection. The virus was harvested after $24 \mathrm{~h}$ incubation, and purified in Percoll (Pharmacia, Sweden) gradients [23].

\subsection{Inhibitors of cholesterol synthesis}

The inhibitors used were cerulenin, W-7 and miconazole (Sigma). Cerulenin was dissolved in methanol/ chloroform $(5: 1)$ and stored at $-20^{\circ} \mathrm{C}$.

For studying the effect of cholesterol synthesis inhibitors on ASFV infection, the virus (1-2 pfu/cell) was adsorbed to cells for $2 \mathrm{~h}$ at $4^{\circ} \mathrm{C}$ in the presence of various concentrations of the inhibitors. Then the medium was removed and the cells were incubated at $37^{\circ} \mathrm{C}$ with new medium with the same concentrations of the drugs. The yield of viruses was determined $24 \mathrm{~h}$ post infection, when extensive c.p.e. was achieved in the control infected cells without the inhibitors.

\subsection{Virus binding}

Briefly, virus binding was measured as previously described [24]. Vero cells were grown to confluence $\left(10^{6}\right.$ cells/dish $)$ in Petri dishes of $35 \mathrm{~mm}$ diameter $\left(\mathrm{P}_{35}\right)$ washed twice with cold PBS, and cooled $\left(4^{\circ} \mathrm{C}\right)$ for $15 \mathrm{~min}$. Labeled ASFV (3-5 pfu/cell) in $200 \mu \mathrm{l}$ of ice-cold PBS was added to each Petri dish, and the dishes were gently shaken for $2 \mathrm{~h}$ at $4^{\circ} \mathrm{C}$. Following this incubation, the free virus was removed and the cell monolayers were washed twice with cold PBS. Cells were then scraped from the dishes, the dishes were washed twice with cold PBS, and the cells were pelleted by low speed centrifugation. Bound virus is defined as that virus which was cell-associated under these conditions. After removal of the supernatant, cells were lysed by addition of PBS containing 1\% SDS for $1 \mathrm{~h}$ at $0^{\circ} \mathrm{C}$. One hour after the addition of an equal volume of cold 20\% TCA, the precipitates were collected on a Millipore filter $(\mathrm{GF} / \mathrm{C})$, washed 
with 5\% TCA and the radioactivity determined in a Beckman LS-100 liquid scintillation spectrometer [24].

\subsection{Virus endocytosis}

Measurements of virus uptake (endocytosis) were performed after warming the samples of infected cells, following virus binding, for various periods at $37^{\circ} \mathrm{C}$ in DME. Following incubation of labeled virus with cells, the medium was removed, the cells were washed with cold PBS and incubated with proteinase $\mathrm{K}$ in PBS $(500 \mu \mathrm{g} / \mathrm{ml})$. After $1 \mathrm{~h}$ of shaking at $4^{\circ} \mathrm{C}$, the cells were washed and scraped in PBS containing $0.2 \%$ bovine serum albumin (BSA) and $1 \mathrm{mM}$ phenylmethylsulfonyl fluoride (PMSF). Cell-associated radioactivity (internalized virus) was determined as described before for the binding experiments. Proteinase $\mathrm{K}$ digestion allowed to separate surfacebound from internalized viruses [24].

\subsection{Virus fusion}

For fusion studies, $\left[{ }^{3} \mathrm{H}\right]$ thymidine-labeled ASFV was bound to cells as described above, cells were incubated at $37^{\circ} \mathrm{C}$ in medium at low $\mathrm{pH}(20 \mathrm{mM}$ succinate buffer, $\mathrm{pH}$ 5.5) to trigger virus-plasma membrane fusion, non-fused virus removed by proteinase $\mathrm{K}$ digestion, and cell-associated radioactivity determined, as before [24].

\subsection{Virus penetration (uncoating)}

For penetration assays $\left[{ }^{3} \mathrm{H}\right]$ thymidine-labeled ASFV was prebound to cells and internalized as described before [24]. At given intervals the samples were placed on ice to stop the process. The supernatant was removed and total and soluble radioactivity was assayed following protein precipitation with $10 \%$ TCA at $0^{\circ} \mathrm{C}$. The cells were overlaid with cold PBS containing $10 \mathrm{mM} \mathrm{MgCl}_{2}$ [25], removed from the dishes by scraping, transferred to Eppendorf tubes at $0^{\circ} \mathrm{C}$ and pelleted for $30 \mathrm{~s}$ in a Beckman microfuge at $4^{\circ} \mathrm{C}$. The supernatant was aspirated and the same buffer added. The cells were passed 30 times through a 24 gauge needle at $0^{\circ} \mathrm{C}$ which resulted in more than $99 \%$ lysis [26]. PBS containing $200 \mu \mathrm{g} / \mathrm{ml}$ of DNase (Sigma) was added to each sample and the samples warmed to $37^{\circ} \mathrm{C}$ for $30 \mathrm{~min}$. Parallel experiments were done without added nuclease to obtain the background breakdown by cellular nucleases. The samples were finally cooled to $0^{\circ} \mathrm{C}$, precipitated by adding an equal volume of $20 \%$ TCA at $0{ }^{\circ} \mathrm{C}$, incubated for $1 \mathrm{~h}$ and the soluble radioactivity determined as described above. All experiments were performed at least twice.

\subsection{Depletion of cellular cholesterol}

Vero cells were partially depleted of cholesterol by growing for 3 days in DME with $8 \%$ delipidated FCS (Sigma). During the last $24 \mathrm{~h}$ of growth, $10 \mu \mathrm{g} / \mathrm{ml}$ of miconazole was added to this medium. Cholesterol was assayed with the Boehringer Mannheim Diagnostics High Performance K-kit. The protein concentration was determined by Lowry-Peterson assay [27].

\subsection{Cholesterol oxidase treatment of cells and virus}

For maximal oxidation, Vero cells and purified virus were prefixed with $2 \%$ glutaraldehyde for $15 \mathrm{~min}$ on ice, and treated for $1 \mathrm{~h}$ with cholesterol oxidase $(5.5$ or $11 \mathrm{U} / \mathrm{ml})$ in $310 \mathrm{mM}$ sucrose and $0.5 \mathrm{mM} \mathrm{Na}_{3} \mathrm{PO}_{4}, \mathrm{pH} 7.4$ [28]. For infectivity studies the enzymatic treatment was performed without previous fixation.

\subsection{Lipid analysis}

For chromatographic analysis of the lipids, viral lipids were extracted from enzyme-treated and untreated virus, which were lyophilized in a conical centrifuge tube and the resulting dry powder was immersed in $0.1 \mathrm{ml}$ of chloroform/methanol (1:1). After warming the mixture for a few minutes at $40^{\circ} \mathrm{C}$, all the chloroform/methanol extract was transferred as one spot on a silica gel $G$ plate. Cellular lipids from oxidase-treated cells or cholesterol depleted cells were extracted as previously described [29], and the lipid extracts were concentrated under $\mathrm{N}_{2}$ atmosphere and spotted together with standards on silica gel $\mathrm{G}$ plates. The plates were developed and visualized by $\mathrm{I}_{2}$ vapor. 
Table 1

Effect of inhibitors of cholesterol synthesis on ASFV infectivity

\begin{tabular}{lll}
\hline Drug & $\begin{array}{l}\text { Concentration } \\
(\mu \mathrm{g} / \mathrm{ml})\end{array}$ & $\begin{array}{l}\text { Replicative cycle } \\
\text { inhibition }(\% \text { control })\end{array}$ \\
\hline W-7 & 2.5 & 78 \\
Cerulenin & 4 & 50 \\
& 2.5 & 87 \\
Miconazole & 5 & 60 \\
\hline
\end{tabular}

The drug was present all the time after infection (1-2 pfu/cell), and the titers were determined by plaque assay at $24 \mathrm{~h}$ post infection. Each value represents the average of three separate experiments. All drugs were used at non-cytotoxic concentrations.

\section{Results}

We explored several methods to assess the importance of cholesterol in the infectious pathway of ASFV. First, we used several inhibitors of cholesterol synthesis (W-7, cerulenin, and miconazole). The results in Table 1 indicate that all inhibitors studied at non-cytotoxic concentrations (maximal non-cytotoxic concentrations were determined by Finter assay [30]) decreased significantly the viral yield. Second, Vero cells or purified ASFV were treated with cholesterol oxidase, which specifically oxidizes the $3 \beta$ hydroxyl group of cholesterol to produce cholesterone [28], and tested for binding, fusion ability and infectivity. The results presented in Table 2 indicate that the binding of purified ASFV to oxidase or mock-treated cells in the cold was identical. Similar results were also obtained for the binding and infectivity of the treated virus. However, fusion at low $\mathrm{pH}$

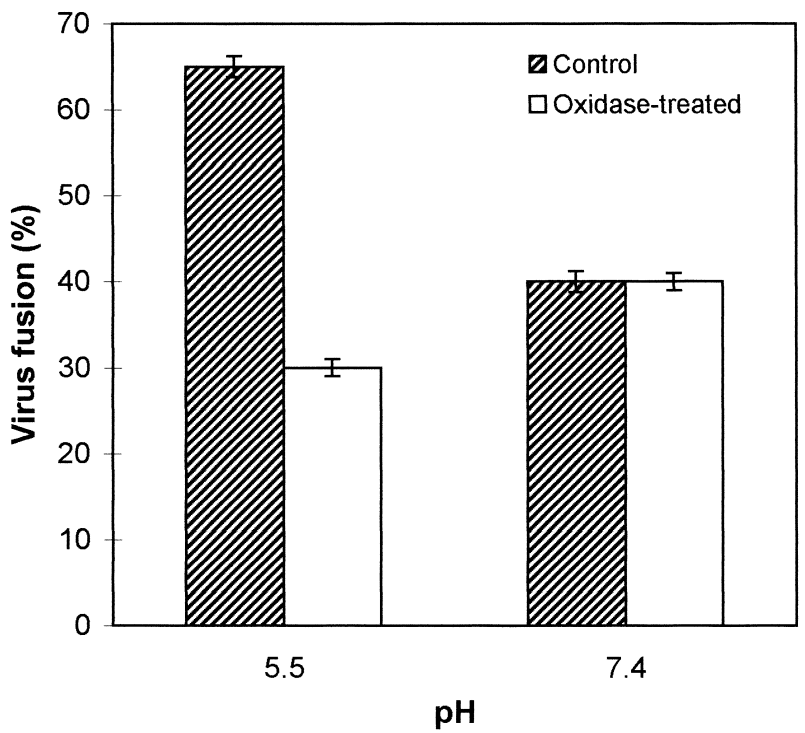

Fig. 1. Effect of cholesterol oxidase treatment of Vero cells on ASFV fusion activity. Vero cells in suspension were pretreated with cholesterol oxidase as described in Section 2. $\left[{ }^{3} \mathrm{H}\right]$ Thymidine-labeled ASFV was bound at $4^{\circ} \mathrm{C}$ to cholesterol oxidase or mock-treated cells at $\mathrm{pH} 7.4$, non-bound virus was removed by washing, and the cells were incubated for $5 \mathrm{~min}$ at either $\mathrm{pH} 7.4$ or 5.5 at $37^{\circ} \mathrm{C}$ to induce virus fusion with the plasma membrane. Non-fused virus was removed by digestion with proteinase $\mathrm{K}$, and fusion was expressed as the percentage of radioactivity of the initially bound virus which became protease resistant.

of the virus previously bound to oxidase-treated cells was significantly inhibited (Fig. 1, Table 2). Under these conditions, the oxidation of cellular cholesterol was $54 \%$. It is interesting to note that fusion at low $\mathrm{pH}$ of cholesterol oxidase-treated virus with the plas-

Table 2

Binding, fusion and infectivity of cholesterol oxidase-treated ASFV or Vero cells

\begin{tabular}{lllrr}
\hline $\begin{array}{l}\text { Cholesterol oxidase } \\
\text { concentration }(\mathrm{U} / \mathrm{ml})\end{array}$ & $\begin{array}{l}\text { Treated cells or } \\
\text { treated virus }\end{array}$ & Binding $(\%$ control) & Fusion $(\%$ control) & Infectivity (\% control) \\
\hline 5.5 & Vero cells & 102 & 62 & ND \\
& ASFV & ND & 98 & 85 \\
11 & ASFV & 99 & ND & 100 \\
\hline
\end{tabular}

Vero cells in suspension were pretreated with cholesterol oxidase as described in Section 2. $\left.{ }^{3} \mathrm{H}\right] \mathrm{Thymidine}-\mathrm{labeled}$ ASFV (3-5 pfu/ml), strain Lisbon 60 was bound at $4^{\circ} \mathrm{C}$ for $2 \mathrm{~h}$ to enzyme- or mock-treated cells. Binding was expressed as the percentage of radioactivity of control bound virus. The same virus preparation $(3-5 \mathrm{pfu} / \mathrm{ml})$ was treated or not with cholesterol oxidase, and binding was expressed as described above. For fusion assays, following treatment of virus or cells with cholesterol oxidase, fusion was induced by incubation at acidic $\mathrm{pH}$ for $5 \mathrm{~min}$ at $37^{\circ} \mathrm{C}$. Non-fused virus was removed by digestion with proteinase $\mathrm{K}$, and fusion expressed as the percentage of radioactivity of control bound virus which became protease resistant. For infectivity experiments, following enzymatic treatment of the virus, ASFV (1-2 pfu) was inoculated into the cells and the viral titers were calculated $24 \mathrm{~h}$ post infection, and expressed as the percentage of control viral titer. Each value represents the average of three separate experiments. ND, not done. 

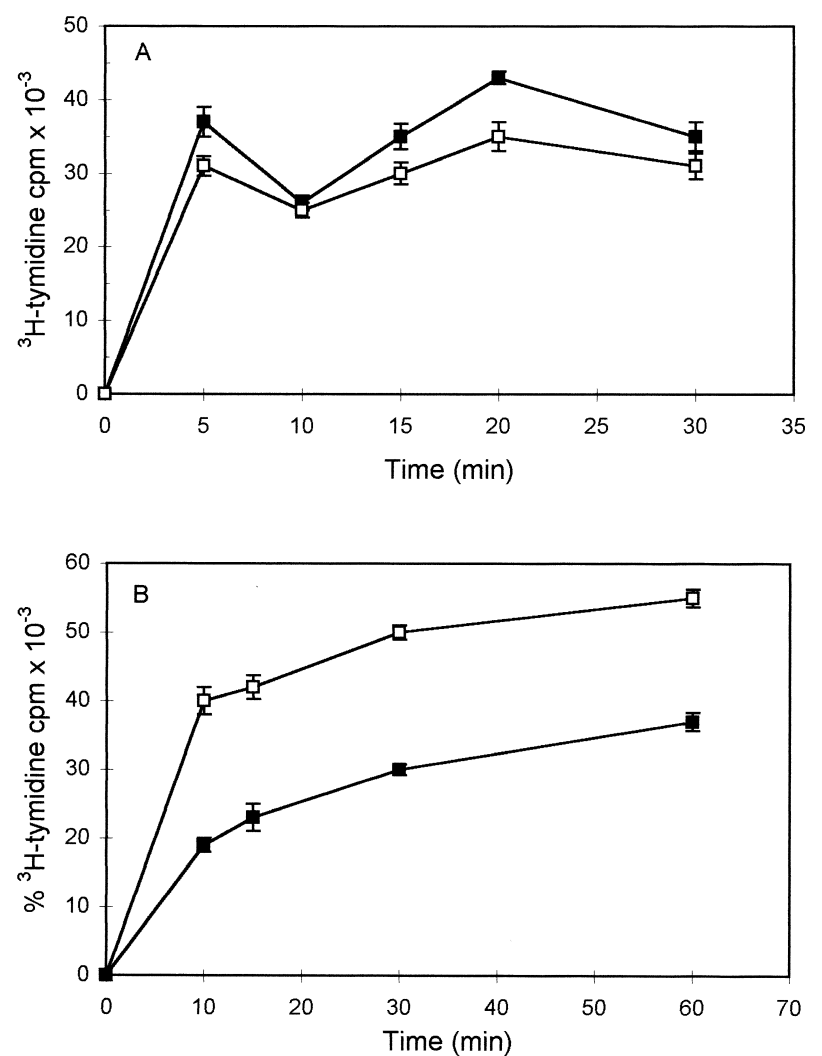

Fig. 2. Kinetics of ASFV endocytosis and DNA penetration in control and cholesterol-depleted Vero cells. (A) Endocytic uptake. $\left[{ }^{3} \mathrm{H}\right]$ Thymidine-labeled ASFV was prebound for $120 \mathrm{~min}$ at $4^{\circ} \mathrm{C}$ to control $(\square)$ or cholesterol-depleted ( $\square$ ) Vero cells at $\mathrm{pH} 7.4$, and the non-bound virus was removed by washing. The cells were warmed to $37^{\circ} \mathrm{C}$ for the indicated period, extracellular viruses stripped off by proteinase $\mathrm{K}$ digestion, and radioactivity of internalized virus was counted. (B) Kinetics of viral DNA delivery into the cytoplasm. $\left[{ }^{3} \mathrm{H}\right]$ Thymidine-labeled ASFV was prebound and internalized as described in A. At the indicated times, the cells were homogenized and the accessibility of viral DNA to degradation by exogenous DNase was assayed. Viral DNA penetration is expressed as the percentage of radioactivity of endocytosed viral DNA that was degraded by DNAse.

ma membrane of non-treated cells was essentially identical to that for non-treated virus (Table 2).

Vero cells can be depleted of cholesterol using delipidated serum and miconazole in the culture medium. After $72 \mathrm{~h}$ of culture under depleting conditions, cholesterol levels were found to have declined to $56 \%$ of those for control cells (data not shown). We then followed the steps of viral entry into these cells, and the results obtained for the binding (not shown) and endocytic uptake of ASFV were compa- rable for control and cholesterol-depleted cells, showing that the cells were essentially healthy after substantial depletion (Fig. 2A). However, viral penetration was significantly decreased in cholesterol-depleted cells, as illustrated by a lower rate of DNA release (Fig. 2B). These results show that sterol depletion decreased intracellular virus fusion, but that the levels of sterol in the depleted cells were still sufficient to allow some fusion. Curiously, low pHinduced fusion at the plasma membrane in these cells was essentially blocked (Fig. 3).

The images obtained by electron microscopy (results not shown) showed that following cholesterol oxidase treatment, the viral and cellular membrane integrity remains unaffected. A comparison of the two-dimensional thin-layer chromatograms for control and cholesterol oxidase-treated cells or cholesterol-depleted cells showed no difference between the phospholipid composition of the three cell preparations. However, the cholesterol spots were significantly decreased in both cholesterol-depleted or oxidase-treated cells (data not shown).

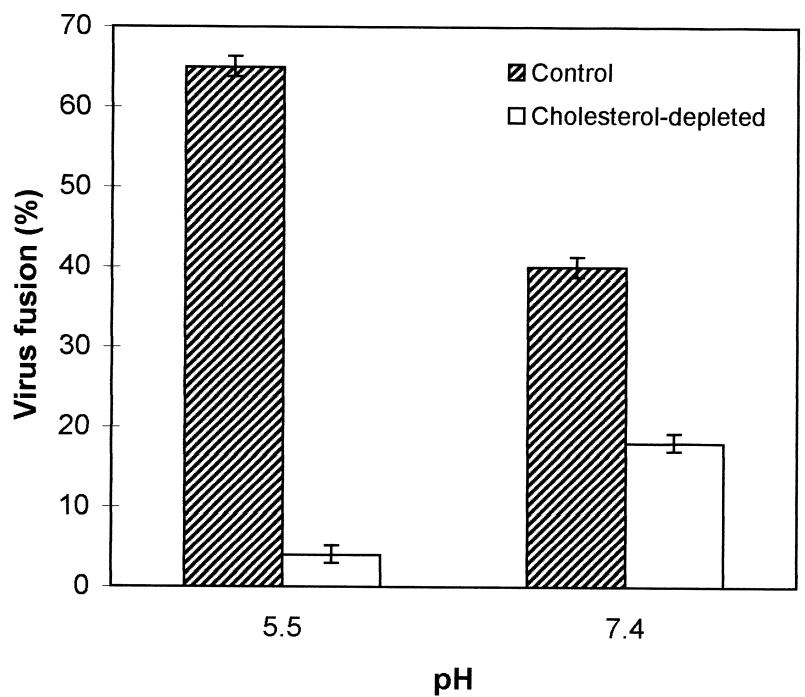

Fig. 3. Effect of cholesterol depletion of Vero cells on ASFV fusion activity. Vero cells were depleted of cholesterol by growing in DME with $8 \%$ delipidated FCS and $10 \mu \mathrm{g} / \mathrm{ml}$ of miconazole. $\left[{ }^{3} \mathrm{H}\right]$ Thymidine-labeled ASFV was bound at $4{ }^{\circ} \mathrm{C}$ to control or cholesterol-depleted cells at $\mathrm{pH} 7.4$ and non-bound virus removed. The cells were then incubated for $5 \mathrm{~min}$ at $37^{\circ} \mathrm{C}$ at either $\mathrm{pH} 7.4$ or 5.5 to induce virus fusion with the plasma membrane. Non-fused virus was removed by digestion with proteinase $\mathrm{K}$, and fusion was expressed as the percentage of radioactivity of the initially bound virus which became protease resistant. 


\section{Discussion}

Taken together, these results demonstrate that cholesterol is required to allow ASFV fusion with the endosome membrane of the host cell. Our studies suggest that this sterol requirement for ASFV fusion is an essential feature of the target plasma membrane, rather than that of the virus membrane. Thus, although purified virus particles contain cholesterol in the virus membrane, they require cholesterol in the target membrane in order to efficiently fuse. The inhibition of fusion and infection in cholesterol oxidase-treated cells suggests that this sterol $3 \beta$-hydroxyl group is required for ASFV fusion with a complex biological membrane.

The sterol depletion in Vero cells decreased intracellular virus fusion and blocked the low $\mathrm{pH}$-induced fusion with the cell membrane more drastically than in cholesterol oxidase-treated cells. This difference may be explained by the fact that artificially induced fusion at the plasma membrane requires more cholesterol than intracellular fusion and/or that sterol depletion is more pronounced in the plasma membrane compared to that of the endosomal membrane. The need of cellular cholesterol is also demonstrated by the results obtained with cholesterol oxidasetreated virus. Binding, low $\mathrm{pH}$-induced fusion with the plasma membrane, and infectivity of the treated virus are not altered as compared to the control virus.

The cholesterol requirement in the entry pathway of some enveloped viruses is well demonstrated for alphaviruses [10,11]. These studies [11] have shown that cholesterol is necessary and sufficient for low $\mathrm{pH}$-dependent binding of SFV to liposomes, while sphingolipids are essential for induction of the actual fusion event. However, other enveloped viruses that use endocytosis and low $\mathrm{pH}$ to infect cells do not have a similar sterol requirement. Both influenza virus, an orthomyxovirus, and VSV, a rhabdovirus, have cholesterol-independent fusion mechanisms [31,32]. Some non-enveloped viruses, such as poliovirus, are known to enter cells via endocytosis and to require a low $\mathrm{pH}$ membrane translocation step, but cholesterol is not an essential component of the membrane [33].

When the viruses do not need cholesterol in the target membrane for infection, it seems that they require this sterol in their membrane. In the case of VSV, when the cholesterol content on its membrane decreases, the infectivity of the virus is affected adversely [20]. Treatment of influenza virus with cholesterol oxidase reduces the hemolytic activity of the virus, but does not appear to alter its cell-cell fusion activity [34]. It is known that the lack of cholesterol can modify the conformational state of viral fusion proteins and affect the insertion of the hydrophobic sequences of these proteins into the target membrane [35].

ASFV does not appear to require cholesterol in its membrane, but the presence of this lipid in the target membrane is important for infection.

The crucial role of cholesterol in the ASFV infectious entry into cells is also illustrated by the low viral yield obtained in the presence of several compounds which interfere with cholesterol metabolism. It has been reported that $\mathrm{W}-7$, cerulenin, and miconazole inhibit the cell fusion induced by measles virus by changing the environment of the fusion protein and possibly its conformation [16].

Studies are currently in progress to investigate the role of other lipids in the early stages of ASFV infection. It will be interesting to know whether sphingolipids are involved in the process of activation of ASFV uncoating.

\section{Acknowledgements}

This work was supported by a JNICT (Portugal) Research PRAXIS Project, 3/32/AGR/09.

\section{References}

[1] O. Arzuza, A. Urzainqui, J.R. Díaz-Ruiz, E. Tabarés, Arch. Virol. 124 (1992) 343-354.

[2] J.V. Costa, in: G. Darai (Ed.), Molecular Biology of Iridoviruses, Kluwer Academic Publishers, Boston, MA, 1990, pp. 247-270.

[3] M.L. Valdeira, A. Geraldes, Biol. Cell. 55 (1985) 35-40.

[4] A. Alcamí, A.L. Carrascosa, E. Vinuela, Virology 168 (1989) 393-398.

[5] M.L. Valdeira, A. Geraldes, in: Proceedings of XIth International Congress on Electron Microscopy, Kyoto, 1986, pp. 3415-3416.

[6] C. Bernardes, M.L. Valdeira, J. Ramalho-Santos, M.C. Pedroso de Lima, Biochem. Mol. Biol. Int. 37 (1995) 481-488. 
[7] J. White, A. Helenius, Proc. Natl. Acad. Sci. USA 77 (1980) 3473-3477.

[8] M.C. Kielian, A. Helenius, J. Virol. 52 (1984) 281-283.

[9] N. Düzgünes, T.M. Allen, J. Fedor, D. Papahadjopoulos, in: S. Ohk, D. Doyle, T.D. Flanagan, S.W. Hui, E. Mayhew (Eds.), Molecular Mechanisms of Membrane Fusion, Plenum Press, New York, 1988, pp. 543-555.

[10] T. Phalen, M. Kielian, J. Cell Biol. 112 (1991) 615-623.

[11] J.L. Nieva, R. Bron, J. Corver, J. Wilschut, EMBO J. 13 (1994) 2797-2804.

[12] M.C. Hsu, A. Scheid, P.W. Choppin, Virology 126 (1983) 361-369.

[13] A.M. Haywood, B.P. Boyer, Biochemistry 23 (1984) 41614166.

[14] M. Daya, M. Cervin, R. Anderson, Virology 163 (1988) 276 283.

[15] I. Filipovic, E. Buddecke, Lipids 22 (1987) 261-265.

[16] E. Malvoisin, W. Fabian, Biochim. Biophys. Acta 1042 (1990) 359-364.

[17] S.W. Hui, C.M. Stewart, M.P. Carpenter, T.P. Stewart, J. Cell Biol. 85 (1980) 283-291.

[18] A. Yoshimura, T. Kobayashi, K. Hidaka, M. Kuwano, S.I. Ohnishi, Biochim. Biophys. Acta 904 (1987) 159-164.

[19] M. Kielian, A. Helenius, J. Cell Biol. 101 (1985) 2284-2291.

[20] R. Pal, Y. Barenholz, R.R. Wagner, Biochemistry 20 (1981) 530-539.
[21] M. Ozawa, A. Asano, J. Biol. Chem. 256 (1981) 5954 5956.

[22] J. Manso-Ribeiro, J.A. Rosa Azevedo, Bull. Off. Int. Epizoot. 55 (1961) 88-106.

[23] M.L. Valdeira, M.C. Duque-Magalhães, A. Geraldes, Arch. Virol. 113 (1990) 125-131.

[24] M.L. Valdeira, C. Bernardes, B. Cruz, A. Geraldes, Vet. Microbiol. (1998) in press.

[25] U. Svensson, R. Persson, J. Virol. 51 (1984) 687-694.

[26] S.W. Gollins, J.S. Porterfield, J. Gen. Virol. 67 (1986) 19411950.

[27] G.L. Peterson, Anal. Biochem. 83 (1977) 346-356.

[28] Y. Lange, B.V. Ramos, J. Biol. Chem. 258 (1983) 1513015139.

[29] R.C. Aloia, H. Tian, F.C. Jensen, Proc. Natl. Acad. Sci. USA 90 (1993) 5181-5185.

[30] N.B. Finter, J. Gen. Virol. 5 (1969) 419-427.

[31] J. White, A. Helenius, J. Kartenbeck, EMBO J. 1 (1982) 217-222.

[32] O. Eidelman, R. Schlegel, S. Tralka, R. Blumenthal, J. Biol. Chem. 259 (1984) 4622-4628.

[33] K. Lonberg-Holm, L.B. Gosser, E.J. Shimshick, J. Virol. 19 (1976) 746-749.

[34] R.T.C. Huang, G. Uslu, J. Biol. Chem. 261 (1986) 1291112914.

[35] K. Asano, A. Asano, Biochem. Int. 10 (1985) 115-122. 